\title{
The Second Anniversary of the Constitutionalisation of the French Charter for the Environment: Constitutional and Environmental Implications
}

\section{David Marrani}

Constitutionalisation, Bill of Rights, precautionary, prevention, comparative environmental law, French Charter for the Environment

\begin{abstract}
The former French president J. Chirac will most likely be remembered for his international standing against the US and domestically, within France, for having initiated a major 'Bill of Rights', the Charter for the Environment and for its constitutionalisation.
\end{abstract}

Two years on, it is time for an assessment and analysis of the Charter's outcomes. In this paper, I will consider whether or not the Charter has achieved what was expected of it, if it does 'enshrine an humanist ecology' while at the same time completing the 1789 Declaration of the Rights of Man and of the Citizen.

\section{INTRODUCTION}

Happy second anniversary to the constitutionalisation of the French Charter for the Environment! Two years ago, France completed a long and interesting process of elaboration of a new 'bill of rights' which was then incorporated in the French legal system via its constitutional order as a constitutional amendment. On Monday 28 February 2005, the French Fifth Republic Constitution was modified. Two texts were presented on the same day to the members of the French Parliament meeting in its 'constitutional' form, the Congrés. ${ }^{1}$ The first constitutional bill contained 4 articles with a proposal for the modification of article 88-1, 88-5 and title XV of the Constitution. ${ }^{2}$ The second bill concerned the introduction of a reference to the Charte de l'environnement, the Charter for the Environment, ${ }^{3}$ in the Preamble of the Constitution. ${ }^{4}$ The two proposed amendments were

* Lecturer in Public and Comparative Law, School of Law, University of Essex, Wivenhoe Park, Colchester, CO4 3SW, UK; e-mail: dmarrani@essex.ac.uk. This is a revised version of a paper delivered to the environmental law subject section meeting at the 2006 SLS annual conference (Keele). The author wishes to thank Cliona Marrani, David Ong, Maurice Sunkin, Audrey Guinchard and Richard Cornes for their help in writing and reviewing this paper. All translations by the author.

1 As provided by art. 89 of the 1958 Constitution. Accessible at www.legifrance.gouv.fr

2 The 4th article of the constitutional bill was supposed to create an exception to the application of the new art. 88-5. This article was meant to make compulsory a referendum regarding future inclusion of member states to the EU. The exception means that this would not apply to Bulgaria, Romania and Croatia.

3 Hereafter referred to as 'the Charter'.

4 The first paragraph of the Preamble was completed by 'ainsi que les droits et devoirs définis dans la Charte de l'environnement de 2004' (and to the rights and duties as defined in the Charter for the Environment of 2004) and is now as follows: The French people solemnly proclaim their attachment to the Rights of Man and the principles of national sovereignty as defined by the Declaration of 1789 , confirmed and complemented by the 1946 Constitution Preamble, and to the rights and duties as defined in the Charter for the Environment of 2004. The Charter has been adopted as statute law in 2004 and became part of the constitutional norm in 2005. 
very interesting in their nature, substance and outcome. The first bill was submitted as a prerequisite to prepare the way for the referendum on the ratification of the treaty establishing a Constitution for Europe. Although this first modification of the Constitution was successful, ${ }^{5}$ we know the outcome of the referendum. ${ }^{6}$ The second modification also passed $^{7}$ and I aim here to show that the outcome of this amendment was indeed very successful, creating a nice equilibrium with the resounding failure of the former amendment. In this paper, I will discuss the evolution of the expected outcomes of the Charter, as well as highlighting the unforeseen but arguably welcome implications of the Charter.

The constitutionalisation of environmental issues has been considered in many international and European constitutions. If we concentrate only on the European constitutions, ${ }^{8}$ we find a rather eclectic catalogue of levels of consideration given to environmental issues. The Spanish Constitution, for example, recognises, in article 45, the right to enjoy an environment appropriate to the development of the person, and the duty to preserve it. It gives a general duty to public authorities to have this principle respected and through article 53, the duty is extended to the legislative power. ${ }^{9}$ The Italian Constitution protects, in a general fashion, the fundamental right to health in its article 32 . While the Portuguese Constitution presents a right to have ones health safeguarded (article 64), and a right to a healthy and ecologically balanced human environment (article 66), both articles include detailed mechanisms to defend these rights. ${ }^{10}$ The German Constitution considers, in article 20a, the fundamental protection of the basis of life, ${ }^{11}$ while the Greek Constitution lists, in article 24, many considerations for the environment, the primary one being inserted in the beginning of paragraph 1: Protection of natural and cultural environment constitutes an obligation of the state. ${ }^{12}$ What is primarily noticeable here is the proposed method of including environmental issues within the constitutional texts. An environmental 'bill of rights' does not appear to have been the way chosen by any other European country except France and this will be examined in detail later.

Although it has in recent years lost pace in both its economic standing and in the European integration debate, France leads the debate in the promotion of rights, as it did in the 18th century with the Declaration of the Rights of Man and of the Citizen, and in the 19th century with its Code civil. With the Charter, France has entered a new era in its arrangement of its constitutional norms. In Europe, constitutions generally are at the apex of the hierarchy of norms, with the principle of legality operating a mechanism of inferior norms respecting superior ones. Supreme, or Constitutional courts ensure the respect of the fundamental norms by inferior courts and frame the work of the legislature. The Fifth Republic Constitution followed that trend while departing from those of the previous Republics in two ways that are of interest to this paper. First, the weakening of the Parliament and second, the creation of a constitutional court, the Conseil constitutionnel. The two combined meant that the Constitution was put at the apex of the

5 The result of the Congrés's vote was 730 for and 66 against.

6 'La France devient le premier pays européen à rejeter la Constitution' Le Monde, (Paris) 30 May 2005. The Ministère de l'intérieur, French home office, gave an official result of 54.87\%: 'no' and 45.13\%: 'yes'.

7 The result of the Congrés's vote was 531voted for and 23 against.

8 See the answer of the Ministre de l'écologie et du développement durable, Réponse à la question écrite $\mathrm{n}^{\circ}$ 05714 of 13 February 2003, posée par M. Oudin (Jacques) from the groupe UMP, JO Sénat 31 July $2003,2468$.

9 http://www.congreso.es/ingles/funciones/constitucion/titulo_1 cap 3.htm and http://www.congreso.es/ ingles/funciones/constitucion/titulo_1_cap_4.htm (last accessed 20 October 2006).

10 See: http://www.quirinale.it/costituzione/costituzione.htm and http://www.parlamento.pt/ingles/cons_leg/ crp_ing/ (last accessed 20 October 2006).

11 ee: http://www.bundestag.de/htdocs_e/info/germanbasiclaw.pdf (last accessed 20 October 2006).

12 See: http://www.parliament.gr/english/politeuma/syntagma.pdf (last accessed 20 October 2006).

E N V L R E V $\left.10 \begin{array}{llllllll}2 & 0 & 0 & 8\end{array}\right) \quad 9-27$ 10 
hierarchy of norms in France. Since 1958, a bill can be referred to the Conseil constitutionnel ${ }^{13}$ for constitutional control. Since $1971,{ }^{14}$ the Conseil constitutionnel has extended its jurisdiction above the articles of the Constitution. It recognised as part of a bloc de constitutionnalité, ${ }^{15}$ a corpus of constitutional norms, the Preamble of the 1958 Constitution, itself referring to the former declaration of rights, and public and civil liberties. ${ }^{16}$ As it stands, an addition to the Preamble is sufficient to extend the bloc de constitutionnalité, i.e. the constitutional norms. This is precisely what has been done by the 2005 constitutional amendment. From now on, the reference to the Charter in the Preamble, as it does for the other bill of rights (the 1789 Declaration and the 1946 Constitution Preamble) ${ }^{17}$ allows the Conseil constitutionnel to review the constitutionality of a bill by reference to it. Bills containing provisions which could be in breach of the Charter will be censured and never be enacted as (statute) law. Finally, one could foresee a large development of the entire framework of French environmental law. The addition of a new 'bill of rights', consecrating environmental issues in the Constitution of the French Fifth Republic, was supposed to change and influence the legislative quality of the acts of the French parliament, mainly as an instrument of constitutional control. What is very important in matters of constitutional rights is how these can be enforced. Indeed, if elaborating rights may be considered satisfactory for a governing body, having one or more mechanisms to concretely protect them is a sign of an efficient respect of the rule of law. It now seems that the influence of the Charter has surpassed all hopes. One should be glad to learn that after an interesting historical development, ${ }^{18}$ what was supposed to be a rather dull document, a mere addendum to the French Constitution, appears to have had a far greater impact than was initially expected. ${ }^{19}$

\section{THE INTERESTING HISTORICAL DEVELOPMENT OF THE CHARTER}

The Charter, this new 'bill of rights', had a rather unusual conception. The other two French bills of rights were adopted by representatives of the Nation assembled in constituent form without any preliminary consultation. Both were 'top-down' documents, elaborated by a certain political elite, driven by political and philosophical considerations. In the case of the Charter, a mixed procedure was used, with a dose of 'bottom-up', associating citizens to the process.

13 A bill may be referred to the Conseil constitutionnel by the Head of State, the Prime minister, the President of both chambers of Parliament, and since the constitutional amendment of 1974, by 60 members of either parliament chambers.

14 Décision 71-44 DC 16 July 1971, JORF 18 July 1971, 7114 (Loi complétant les dispositions des articles 5 et 7 de la loi du ler juillet 1901 relative au contrat d'association). See also Recueil, p. 29 and RJC, p. I-24.

15 L. Favoreu and L. Philip, Index thématique des Grandes décisions du Conseil constitutionnel (Dalloz: Paris, 1999). L. Favoreu 'Bloc de constitutionnalité", in O. Duhamel and Y. Meny Dictionnaire constitutionnel, (P.U.F.: Paris, 1992) 87-89.

16 The Bloc de constitutionnalité has a similar meaning as constitutional norm. Is considered to be the constitutional norm the 1958 Constitution, i.e. articles of the Constitution and its Preamble. The Preamble refers to the Declaration of the Right of Man and the Citizen 26 August 1789 and to the 1946 Constitution Preamble. The 1946 Constitution Preamble refers also to the 1789 Declaration and to the Principes fondamentaux reconnus par les Lois de la République, rights and civil liberties recognised by statute laws of the Third French Republic while listing the Principes economiques et sociaux particuliérement nécessaire a notre temps, "socio-economic" rights and civil liberties particularly useful to our time.

17 M. Verpeaux, 'L'enfer constitutionnel est pavé de bonnes intentions', (2004) AJDA Chroniques, 1209.

18 Discussed below.

19 Discussed below. 


\section{ON THE ELABORATION OF THE CHARTER}

President Chirac was the initiator of this new 'bill of rights'. During his first term of office, ${ }^{20}$ he indicated in a speech in Orleans in 2001 his desire for an environmental Charter: 'A new and vast ambition is imposed on everybody, and particularly on us: to make France a new crucible of this new ethic and new way of life for the 21 st century. To enshrine a humanist ecology at the heart of our republican pact'. ${ }^{21}$

During the 2002 presidential election campaign, environmental protection was one of the major issues of Chirac's candidacy. Five points were particularly developed in his programme. Primarily, Chirac presented the preparation of a Charter for the Environment that would rest upon the Constitution and would comprise five fundamental principles: prevention, precautionary, responsibility, integration, and finally, information and participation. Then, there was the idea of the creation of a departmental minister of ecology and sustainable development. Furthermore, Chirac proposed the creation of a World Environment Organisation that would be able to act as a counterweight to the World Trade Organisation (WTO). Furthermore, he then suggested special procedures for regulating the introduction of genetically modified organisms (GMOs), similar to those used in the pharmaceutical industry. Also mentioned was the more specific issue of burying electrical cables, and finally the teaching of ecology, or perhaps more accurately, an ecological consciousness, in schools. ${ }^{22}$

Immediately after his electoral success in 2002, President Chirac began the implementation of his programme. On 5 June that year, the elaboration process of the Charter was launched. The process itself was a peculiar one in the French context. Three weeks later, on 26 June, a commission was established under the authority of the Prime Minister. Professor Coppens, a scientist, was appointed as chair of this committee to supervise the proceedings. ${ }^{23}$ From October 2002 to April 2003, national and local public consultations began through the use of surveys, internet fora and chat services. From January to March 2003 proper assises territoriales, local meetings, were organised.

On 8 April 2003, the Coppens Commission produced a draft of the Charter which was submitted to the Government as a working document. This draft proposal of a constitutional bill was adopted in Conseil des Ministres on 25 June 2003 and sent to the parliament for adoption. ${ }^{24}$ This bill then was successfully passed in the lower chamber (Assemblée Nationale) on 1 June $2004^{25}$ and the upper chamber (Sénat), three weeks later, on the 24 th. ${ }^{26}$ On the 18 February 2005, President Chirac initiated the final part of the process for

20 J. Chirac served a first term of seven years from 1995 to 2002 and a second term of five years from 2002 to 2007 (the duration of the presidential term was amended in 2000).

21 Speech by J. Chirac, Orleans, 3 May 2001. See : http://www.elysee.fr/elysee/francais/interventions/ discours_et_declarations/2001/mai/discours_de_m_jacques_chirac_president_de_la_republique_sur_l_envi ronnement-orleans.3005.html (last accessed 20 October 2006).

22 Speech by J. Chirac, Avranches, 18 March 2002 (Campagne électorale pour l'élection présidentielle). See: http://www.elysee.fr/elysee/francais/interventions/discours_et_declarations/2002/mars/discours_de_m_jacq ues_chirac_a_avranches-campagne_electorale_pour_l_election_presidentielle.919.html (last accessed 20 October 2006).

23 The 'Commission Coppens'.

24 In accordance with art. 89 of the 1958 Constitution, the procedure was initiated by the President of the Republic on the proposal of the Prime Minister, then the bill was passed by the two Assemblies in identical terms. The project of bill (projet de loi constitutionnelle relatif à la Charte de l'environnement) n. 992 was presented before the Assemblée nationale on the 27 June $2003<\mathrm{http} / /$ www.assemblee-nationale.fr/ 12/projets/pl0992.asp > (last accessed 20 October 2006).

25 The result was 328 voted for and 10 against (194 abstentions)

26 The result was 172 voted for and 92 against (47 abstentions).

E N V L R E V $\left.10 \begin{array}{llllllll}2 & 0 & 0 & 8\end{array}\right) \quad 9-27$ 12 
a constitutional amendment by convening the Congrés, which subsequently approved it while modifying the Fifth Republic Constitution on 28 February 2005.27 The President then promulgated the Act on 1 March 2005.28

Not only the design of the Charter but its position within the constitutional norms have a symbolic signification. The Charter was not incorporated in the Preamble or in the articles of the Constitution (like as already mentioned, is the case in many European states). Instead, it was written and approved as a separate text, which was then referred to in a constitutional amendment. Furthermore, reference to the Charter was not introduced in the articles of the Constitution but in the Preamble of the Constitution. Both the 'how' and 'where' contributed to a strong and deliberate wish of continuity in the French tradition of a written 'bill of rights'. The constitutional history of France shows a long list of new 'bill of rights' inserted at the beginning of the text (First and Fourth French Republics for example) or within the text (Second French Republic) of the French Constitutions. In 1958, the idea was to present a concise text with the ability to 'open it up', and amend it, where necessary. The Fifth Republic Constitution did not present a Preamble with a 'bill of rights'. The constituents in 1958 chose instead to make a reference to historically important ones. Even if the Preamble and the articles of the Constitution are both considered by the Conseil constitutionnel, ${ }^{29}$ as being 'the' constitutional norm, it would have been possible to place the Charter within the corpus of articles of the Constitution itself. However, inserting it in the Preamble was instead chosen, maintaining the wish of the original constituents of 1958.

The Charter is the first 'bill of rights' that has been developed since 1946. It has now become a 'third pillar' of rights. Environmental rights are now enshrined within the Preamble of the French Constitution (and in consequence within the French constitutional norm) with the idea that these constitutional rights are rights of man. As for the redaction of the Constitution, the Preamble is simple and precise. The rights of man are those of the liberal rights of the 1789 Declaration. The socio-economic rights of the 1946 Constitution Preamble and the environmental rights of the Charter for the Environment of 2004 complete the 1789 Declaration. The Charter is an investment in and for the future, a sort of 'short circuit that opens the present on the future', 30 to use the expression of G. Deleuze. Indeed, the philosophical substance of the Charter is very significant.

\section{ON THE PHILOSOPHICAL SUBSTANCE OF THE CHARTER}

Theoretically, two major philosophical currents have been contributing to the environmental narratives: the bio-centred deep ecology and the antropo-centred humanist one. As explained by D. Bourg, there are three scenarios of socio-political organisation. The first scenario is a fundamentalist scenario which is attached to a bio-centred deep ecology. The second and the third scenarios are, on the contrary, antropo-centred humanist ones. The second scenario is the authoritarian scenario, that prescribes 'a tyranny well benevolent

27 As provided by art. 89 of the 1958 Constitution, an amendment shall become definitive after approval by referendum although the proposed amendment shall not be submitted to a referendum when the President of the Republic decides to submit it to Parliament convened in Congress; in this case, the proposed amendment shall be approved only if it is accepted by a three-fifths majority of the votes cast. Accessible at www.legifrance.gouv.fr.

28 Loi constitutionnelle 2005-205 of 1 March 2005, (Loi constitutionnelle relative à la Charte de l'environnement (1)), JORF 2 March 2005, 3697.

29 The Conseil constitutionnel is the French constitutional tribunal since 1958.

30 G. Deleuze, 'Le Devenir révolutionnaire et les créations politiques'(May 1990) Futur Anterieur 1. 
and well informed' 31 and the last one, the democratic scenario, follows the sustainable development framework as defined by the Brundtland report. The will of the constituents in 2005 was that the Charter, completes the 1789 Declaration. In that respect, it insures the continuity of the French liberal tradition. The objectives, rules and rights of man listed in its seven considérants and 10 articles illustrate the humanist side of the document. In considering this, the beau texte, the 'nice text', requested by President Chirac, definitely departs from the 'deep ecology' and its fundamentalist scenario. ${ }^{32}$ Indeed, president Chirac considered that: 'To choose humanist ecology, that's a step towards putting man at the centre of all projects and that allows him the responsibility of his destiny'. ${ }^{33}$

The clues that may help us to look at the Charter as anthropo-centered are, the general references to mankind (homme and humanité), the description of the environment as a common patrimony of humanity, the wording similar to that used within the Universal Declaration of Human Rights, ${ }^{34}$ and, finally, the mention of sustainable development incorporating Principle 1 of the Rio Declaration. There is of course, the will of the constituents to create a liberal document that would tend to follow the democratic scenario. If we further analyse the five points that Chirac listed in his speech in 2002, two contain insights that are strongly open to the dialectic of the antropo-centred movement of political ecology. The first point is the teaching of ecology at school and the other is the writing of the Charter itself. Translated into the scenarios of political ecology and linked to the French republican tradition, the teaching relates to the authoritarian scenario, while the idea of a 'bill of rights' relates to the democratic scenario. ${ }^{35}$

\section{Education}

Education has always been considered as a very high priority in France strongly related to the French Revolution and national unity. The French Revolution was primarily a revolution of the mind. And indeed, it was a necessity for the republicans in 1789 to affirm their ideas permanently. The 1791 Constitution (First Constitution) considered education as fundamental. Undeniably, education was considered as the foundation stone of the republican future, underpinning language and nationalism. One nation, one language. So to unify the nation, and to provide a single communication medium for the French revolutionary army, all local dialects had to disappear. Public education was linked to the unity of the French nation via the French language. For this sensitive reason, education can only be within the competence of a central State. As a consequence, it was never transferred to sub-national (local) authorities, and it was always an aide to the dogmatic development of French republicanism. Historically, it was at school that the ideas and ideals of the Republic were (and in a way still are) taught through an official curriculum, preached by the primary school teachers, instituteurs elements of a monolithic centralised system of education. ${ }^{36}$ The instituteurs are ambivalent. As Charles Péguy claimed, the instituteur

31 D. Bourg, Les Scénarios de l'Ecologie (Hachette Paris 1996) and H. Jonas, Le Principe Responsabilité. Une éthique pour la civilisation technologique (Cerf: Paris, 1990).

32 A. Dowson, P. Lucardie, The Politics of Nature (Routledge: London, 1993).

33 See Chirac, above n. 21.

34 Article 17: Each people has the right to use the common patrimony of humanity such as the high seas, the sea floor and celestial space. Universal Declaration of Human Rights (United Nations, 1948).

35 See Dowson, Lucardie, above n. 32.

36 Durkheim who first considered studying education with his sociology of education in the $19^{\text {th }}$ century, was convinced that the instituteurs were recipient of a part of 'holiness' left over from the priest, thus positioning education at the same level as religion. F. Dubet, M. Wieviorka dir. 'La laïcité dans les mutations de l'école'in Une société fragmentée? Le multiculturalisme en débat, (Paris La Découverte 1996). Also, M de Saint Martin, 'Les principales tendances de la sociologie de l'éducation en France' Revue Internationale de l'Education, (1972) 18 (1). 100-107.

E N V L R E V $\left.10 \begin{array}{lllllllll}2 & 0 & 0 & 8\end{array}\right) \quad 9-27$ 
became the representative of humanity, 'représentant de l'humanité'. But, during the French Third Republic, it became hussard noir de la République, a metaphor of the Napoleonic soldier in charge of educating the mind of new generations. Educating the mind for the French Third Republic did not mean simply teaching but rather an authoritarian creation of a republican culture. Militarian discourse and violence of the coercing of a unique language made education authoritarian. The Charter incorporated, in article 8 , (although in a way article 6 may be considered here as well) Chirac's proposal in the 2002 campaign of the teaching of ecology at school. Even before the elevation of the Charter at constitutional level, the text was used as a (philosophical) reference for the department of education. ${ }^{37}$ During the summer 2004, instruction was given to civil servants in charge of education from recteurs d'académie (chef education officers) to headmasters of primary and secondary educational institutions on the application of article 8 of the Charter to 'generalise the education on the environment for a sustainable development from the academic year 2004' ${ }^{38}$ Environmental education (the programme 'EEDD') became a main priority and a fundamental public policy of the French Republic and is now considered as an important part of the curriculum of French primary and secondary schools.

Hence, environmental issues now form part of French republican values that have to be taught to future generations. So, according to the tradition of 'metaphoric militarian aspects of education' (only primary and secondary education), the French Republic is pushing, forcing, environmental issues on the youngest members of the population. One may consider this a noble act, but it may also be said that this implies an authoritarian vision of environmental protection, when linked to the French educational tradition. There is, therefore, in the discourse of the candidate J. Chirac a contradiction. While it respects the French liberal tradition and strongly roots the Charter in the antropo-centered scenario, it falls between an authoritarian and a democratic approach.

\section{Writing the Charter}

As mentioned, in Chirac's programme for the environment, the Charter was meant to take into consideration five 'environmental principles' (prevention, precautionary, responsibility, integration, information and participation) that philosophically relate to the Bruntland report. The incorporation of the Charter into the constitutional norms of the Fifth French Republic intended that these principles, and particularly the prevention principle and the precautionary principle, were to be elevated from legal rights to constitutional rights. The anthropo-centred Charter introduced a hierarchy in environmental principles. The prevention principle is now considered as an objective of constitutional values while the precautionary principle is the (unique) principle of constitutional

37 There is here a parallel with the 1789 Declaration, which was also a philosophical reference until 1971.

38 Circulaire 2004-110 of 8 July 2004, BOEN 28, 15 July 2004, 1473 (Généralisation d'une éducation à l'environnement pour un développement durable (EEDD) - rentrée 2004). It has to be noted that this document replaces a previous one, Circulaire 77-300 of 29 August 1977, BOEN 31, 9 September 1977, 2507 (Instruction générale sur l'éducation des éleves en matiére d'environnement). The requirement to develop teaching on environmental protection was always present in the curriculum through specific educational programmes (on forests and animals for example) but never on a general basis. This generalisation of environmental education follows the first law adopted in 1976 on environmental protection (Loi $n^{\circ} 76-629$ du 10 juillet 1976 relative à la protection de la nature. JORF 13 July 1976 4203). 
values. ${ }^{39}$ The precautionary principle is set at the top of the hierarchy. It is considered specifically in article 5 of the Charter as a 'principle' (principle of constitutional value). And has been known in the French legal order since 1992, after the 'integration' of Principle 15 of the Rio Declaration into French law. Article L.110-1.1 ${ }^{\circ}$ of the Environmental Code considers that under the precautionary principle,

'the absence of certainty, based on current scientific and technical knowledge, must not delay the adoption of effective and proportionate measures aiming to prevent a risk of serious and irreversible damage to the environment at an economically acceptable cost'. ${ }^{40}$

The precautionary principle also receives a proper definition within the Charter.

'Even if scientific knowledge is uncertain where damages occur which could have serious and irreversible effects on their environment, public authorities shall within their own domains of competences, apply the precautionary principle through the implementation of procedures for the evaluation of risks, and the adoption of provisional and proportionate measures in order to prevent the damage occurring'.

But the scope of this right is limited. This principle is expected to apply only to public authorities. It is indicated that the procedure of evaluation of risks and the adoption of provisional and proportionate measures should avoid the occurrence of damage. What is rather interesting is how the text of the Charter is balanced here. The principle of constitutional value 'precautionary principle', concerns only public authorities. This diminishes its scope dramatically. Article 3 of the Charter outlines the prevention principle without referring to it as a 'principle' (it is instead considered as an objective of constitutional values, see table below ${ }^{41}$ ): 'Everyone shall, within the limits imposed by Statute Law, prevent possible damages to the environment one may create or, failing that, limit their consequences'. However, its scope appears to apply to everyone, as does also the new responsibility objective (article 4):'Everyone shall contribute to repairing damages one causes to the environment, within the limits imposed by Law'.

If we look at articles 3 and 4, the two 'objectives of constitutional values', responsibility and precautionary principle, are not as explicit and developed as the 'principle of constitutional value', the prevention principle, included in article 5 . Then again it may be noted that there is a different scope, which balances this lack of precision. The two articles mention 'everyone shall' and therefore are applicable to everyone. In concrete terms, if one

39 It seems that since 1982, the Conseil constitutionnel mentions principes à valeur constitutionnel and objectifs à valeur constitutionnel. For Professor F. Luchaire, the principles of constitutional value are directly applicable and can be invoked by individual before a court while objectives of constitutional value are imposed on the legislative power but are never directly invoked before a court. See Revue Française de Droit Constitutionnel, $\mathrm{n}^{\circ}$ 64, October 2005, 675-684 and the Rapport fait au nom de la Commission des lois constitutionnelles, de la législation et de l'administration générale de la République sur le projet de loi constitutionnelle ( $N^{\circ}$ 992) relatif à la Charte de l'environnement. <http://www.assemblee-nationale.fr/12/ rapports/r1595.asp> (last accessed 20 October 2006).

40 Introduced under the Loi 92-654 du 13 juillet 1992 relative au contrôle de l'utilisation et de la dissémination des organismes génétiquement modifiés et modifiant la loi 76-663 du 19 juillet 1976 relative aux installations classées pour la protection de l'environnement, JORF 16 July 1992 9461. Then again the most important step was the codification operated under the Loi 95-101 du 2 février 1995 Loi relative au renforcement de la protection de l'environnement, JORF 3 February 1995. Since Loi 2002-276 du 27 février 2002 art. 132 JORF 28 February 2002 it appears in the first article (Article L.110-1) of the environment code, Code de l'environnement, enshrining the general principles of environmental law (precautionary, prevention, participation). Accessible in English at http://195.83.177.9/code/liste.phtml?lang=uk\&c=40 (last accessed 1 Oct. 2007).

41 See above n. 39.

$\begin{array}{llllllllllll}\text { ENV L REV I } & 0 & \left(\begin{array}{lllll}2 & 0 & 0 & 8\end{array}\right) \quad 9-2 & -2\end{array}$


uses the example of GMO experimentation, there is a strong possibility of it being considered in breach of article 5 if the experimentation is conducted by a public authority but not if it is conducted by a private company. ${ }^{42}$ The Charter was never meant to be only a philosophical document. It was supposed to be a concrete legal text that only concerns a bill submitted to constitutional control and not any other type of legal action. In fact the philosophical document proved to be more complex than expected and its legal outcome more wide reaching. There has been a certain evolution.

\section{FROM AN EXPECTED IMPACT, TO MULTIPLE IMPACTS ON THE FRENCH LEGAL SYSTEM}

During the legislative debate, the constituents predicted that incorporating a new bill of rights into the numerous French constitutional norms would increase the scope of constitutional control. Mainly, it was considered that the scope of control of the Conseil constitutionnel would be enlarged. This was a consequence of the idea that the preamble of the Charter was specifically supposed to serve as a guide for the control. There has been, in fact, a diversity of impact during the first years of application as authors commented that some articles (like articles 8, 9 and 10) would have no legal effects, while articles 1 to 7 would. ${ }^{43}$ The diversity of impact is strongly related to the differences in the substance of the rights incorporated in the Charter:

\section{EFFECT OF THE CHARTER}

\begin{tabular}{|l|l|l|}
\hline $\begin{array}{l}\text { POLITICAL } \\
\text { EFFECTS/ } \\
\text { UNCLEAR } \\
\text { LEGAL } \\
\text { EFFECTS }\end{array}$ & Declaratory effects & Preamble para. 1, 2, 4, 5 \\
\cline { 2 - 3 } & Operational effects & Preamble para. 3 article 8 to 10 \\
\hline $\begin{array}{l}\text { CLEAR LEGAL } \\
\text { EFFECTS }\end{array}$ & $\begin{array}{l}\text { Objectives of constitutional } \\
\text { values }\end{array}$ & $\begin{array}{l}\text { Preamble para. } 6 \text { and } 7 \\
\text { Article } 1 \text { to } 7\end{array}$ \\
\cline { 2 - 3 } & Principle of constitutional values & Article 5 \\
\hline
\end{tabular}

Source: N.Chahid-Nouraï, 'La portée de la Charte pour le juge ordinaire' (2005) AJDA Chroniques 1175, translated and edited by the author.

\section{POLITICAL EFFECTS/UNCLEAR LEGAL EFFECTS}

President Chirac, in his speech on the first anniversary of the promulgation of the Charter, spoke precisely about the difference between unclear and clear legal effects. On political /unclear legal effects, Chirac mentioned article 8 and discussed its educational importance. He declared that: 'Because it engages our future, the Charter needs to be known by

42 However, if a private company is allowed to experiment it may face responsibility under art. 4 of the Charter

43 Y. Jegouzo, 'La Charte de l'environnement'(2005) AJDA Chroniques, 1156. 
everyone but first by the youngest. It will be studied at school, within an educational program on environment, generalised since 2004'. ${ }^{44}$

The Charter is a document with broad aspects, the primary one being that of a guide for institutions, particularly the French Parliament and Government. The political /unclear legal effects, of the Charter are applied a priori, in the decisions, acts and during policymaking processes of the administration. ${ }^{45}$

'At large, the Charter for the Environment demands all public policies to integrate the need for sustainable development and must be taken into consideration throughout the preparation of texts'. ${ }^{46}$

What the scholars have described as political/unclear legal effects are followed by what may be defined as clear legal effects.

\section{CLEAR LEGAL EFFECTS}

It was manifest from the start that the principles of the Charter were always meant to guide the legislative power in its law making process because of the structure of the hierarchy of norms imposed by the 1958 Constitution, combined with the constitutional control through the Conseil constitutionnel.

'The Conseil constitutionnel [...], examines bills voted by the parliament through the principles of the Charter. And these principles guide the work of the government during the elaboration process of the projects of law. I think particularly about the future law on GMOs or those transposing the environmental liability directive'. ${ }^{47}$

The Charter became a way of new instrument of controlling constitutionality of bills as expected, but it also became a document used in traditional civil and administrative litigations.

\section{Charter and constitutional control}

Since the 2005 constitutional amendment, the reference to the Charter in the Preamble, 48 allows the Conseil constitutionnel to review the constitutionality of a bill by reference to it. Furthermore, it has been argued that Article 1 of the Charter, which proclaims that everyone has the right to live in an environment that is balanced and respects health, constitutes a liberté fondamentale, a fundamental freedom ${ }^{49}$ (as meant by article L. 521-1 of the Code de justice administrative). Bills containing provisions which could be in breach of the Charter will be censured and can never be enacted as Law. On the other hand, proposals (or projects) such as that for an eco-tax could be put forward without risking

44 Speech by J. Chirac, Palais de l'Élysée, 1 March 2006 (premier anniversaire de la promulgation de la charte de l'environnement), See : http://www.elysee.fr/elysee/elysee.fr/francais/interventions/discours_et_declarations/ 2006/mars/allocution_du_president_de_la_republique_a_l_occasion_du_premier_anniversaire_de_la_prom ulgation_de_la_charte_de_l_environnement.42132.html (last accessed 20 October 2006.).

45 This is not without comparison, to some extent, with the HRA 1998 and its guiding purpose to public authorities.

46 See Chirac, above n. 44.

47 See Chirac, above n. 44

48 M. Verpeaux, 'L'enfer constitutionnel est pavé de bonnes intentions'(2004) AJDA Chroniques 1209.

49 H. Groud, S. Pugeault, 'Le droit à l'environnement, nouvelle liberté fondamentale'(2005) AJDA Jurisprudence 1357.

E N V L R E V $\left.10 \begin{array}{llllllll}2 & 0 & 0 & 8\end{array}\right) \quad 9-27$ 18 
censure as was the case eco-tax project from 2000 which was, at that time, censured by the Conseil constitutionnel. 50

An example of this occurred on the 26 October 2005, when a statute which adapted communitarian law brought into force the dispositions of the Charter in areas of evaluation of impacts on environmental projects as well as access to information. Future projects of statutes governing water and aquatic areas, on national parks and natural maritime parks, on GMOs, on transparency and security in nuclear areas, on management of radioactive materials and wastes will all have to take into account the principles of the Charter. Furthermore, article 6 of the Charter promotes sustainable development through all new pieces of legislation made. ${ }^{51}$

Since 2005, many references to the Charter have been made during the process of constitutional control. As mentioned previously, in the landmark 1971 decision ${ }^{52}$ incorporating bills of rights in the Constitution, the Conseil constitutionnel exposed its reasoning in the case of constitutional control involving the Preamble of the Fifth Republic Constitution (rather than the Constitution itself): the constitutional councillors expressly referred to the Constitution and its Preamble, then they incorporated the Preamble in the constitutional norms and finally they associated it in the single term 'Constitution'. It was therefore in the following decisions only necessary to consider the Constitution without specifying which particular texts or parts of the constitutional norms the judges were considering (the Preamble or articles). The implied use of the Preamble became the normal way of operating constitutional control. Therefore, we are facing a similar operation here in the case of the Charter. Two methods of using the Charter by the Conseil constitutionnel can be found chronologically, one express, one implied.

\section{Express uses of the Charter}

In March 2005, ${ }^{53}$ it was suggested that the presidential décret of 9 March 2005 allowing the submission of the bill authorising the ratification of the treaty establishing a Constitution for Europe to referendum was contrary to article 5 of the Charter ${ }^{54}$. The Conseil held that it was not relevant to mention the Charter ${ }^{55}$ and did not, in this case, scrutinise the alleged non-conformity of the statutory instrument. 'Considering, [...], that in any case, the treaty establishing a Constitution for Europe is not contrary to the Charter for the Environment of 2004'.

It was a tremendous opportunity for the Conseil. By expressly declaring that the statutory instrument conforms to the Charter, the Conseil considered it as part of the Constitution, as it had previously in 1971. The only problem of this case was that in its ruling, the Conseil solely considered the position of the Charter but did not substantially consider the Charter itself. Nonetheless, this was subsequently achieved.

50 Décision 2000-441 DC 28 December 2000, JORF 31 December 2000, 21204 (Loi de finances rectificative pour 2000). See also Recueil, p. 201.

51 Communication by Mme N Olin, Conseil des ministres, 1 March 2006. http://www.ecologie.gouv.fr /article.php3?id_article=5253 (last accessed 20 October 2006).

52 See Decision, above n. 14.

53 Décision 24 March 2005 sur des requêtes présentées par Monsieur Stéphane Hauchemaille et par Monsieur Alain Meyet, JORF 31 March 2005, 5834.

54 Ibid., para. 4.

55 Ibid., para. 7. 
In April 2005,56 on a bill concerning the creation of a maritime register, the Charter was used explicitly in paragraphs 13, 36, 37 and 38 of the decision. In paragraph 13, the applicants detailed the texts of parts of the Constitution they wanted to use and included article 6 of the Charter. The Conseil constitutionnel then commented on this argumentation in paragraphs 36 to 38. It was argued that the bill was not contrary to article 6. Paragraph 37 is probably the most important one, as it firmly stated that the application of the dispositions of article 6 had to be left to the discretion of the legislature.

'Considering that following the dispositions of article 6 of the Charter for the Environment of 2004 : 'Public policies must promote sustainable development. For this purpose, they conciliate protection and valorisation of the environment, economic development and social progress; it is a power for the legislature to determine, in the respect of the principle of conciliation laid down by those measures, the terms of its implementation'.

In July 2005,57 a bill was discussed on the energy policies of France. Applicants were trying to get the bill declared incompatible with the Constitution and used, in their argument, the principle of equality enshrined in article 6 of the Charter ${ }^{58}$ to try to convince the constitutional councillors. The Conseil constitutionnel considered that the bill did not infringe article 6.59

As we can see from the above cases, the Charter has been directly used in the process of constitutional control, as was its intention. However, as well as these express uses implied uses of the Charter can also be found in bills relating to environmental issues.

\section{Implied uses of the Charter}

Although a decision of April $2005^{60}$ may be the first attempt at an implied use of the Charter, it was certainly used, in December $2005,{ }^{61}$ during the finance bill discussion that concerned the credits allocated to ecology and sustainable development. ${ }^{62}$

Since then, the implied use of the Charter in matters of constitutional control seems to have been the preferred approach, thus following the traditional fashion of operating constitutional control based on the Preamble since 1971. Then again this has proved to be more difficult to recognise as no major pieces of legislation relating to environmental issues have been brought before the Conseil constitutionnel in 2006 and early 2007, except perhaps the decisions of 30 November $2006^{63}$ on a bill relating to the energy sector and

56 Décision 2005-514 DC 28 April 2005, JORF 4 May 2005, 7702 (Loi relative à la création du registre international français). This bill was declared in conformity with the Constitution.

57 Décision 2005-516 DC 7 July, JORF 14 July 2005, 115892005 (Loi de programme fixant les orientations de la politique énergétique). This bill was declared in conformity with the Constitution.

58 Ibid., para. 23.

59 Ibid., para. 25

60 Décision 2005-513 DC 14 April 2005, JORF 21 April 2005, 6974 (Loi relative aux aéroports). This bill was declared in conformity with the Constitution (para. 12 of the decision concerned the modulations of a tax based on reducing or compensating impacts on the environment).

61 Décision 2005-530 DC 29 Decembre 2005, JORF 31 December 2005, 20705 (Loi de finances pour 2006). This bill was declared partially not to be in conformity with the Constitution.

62 Ibid., paras 11-14.

63 Décision DC 2006-543, JORF 8 December 2006, 18544 (Loi relative au secteur de l'énergie). This bill was declared partially not to be in conformity with the Constitution.

E N V L R E V $\left.10 \begin{array}{llllllllll}2 & 0 & 0 & 8\end{array}\right) \quad 9-2 \quad 7$ 
that of 22 February $2007^{64}$ on a bill relating to the development of the area of La Défense in Paris.

The predicted outcome of constitutional control was, while being qualitatively important, in fact quantitatively very few. This is perhaps why it is interesting to show that in addition to the aforementioned, the first two years of operation of the Charter have seen an unpredicted development of its use by the lower courts.

\section{Charter and administrative and civil/criminal litigation}

If constitutional control was the most definite expected outcome of the Charter, it was somewhat surprising to find it used by French courts. The Charter did, in fact, also provide guidance for the courts under the supervision of the supreme court of the administrative justice system (the Conseil d'État) and the supreme court of the civil and criminal justice system (the Cour de cassation). It is indeed interesting to note that some lower courts of the two jurisdictional orders have used the charter in the same way as the constitutional councillors did. This outcome was most unexpected and transformed the Charter into an operational document.

The Conseil d'Etat was not a novice in environmental, protection. The precautionary principle in its legislative version has long been a reference point for operating judicial review. Since the transposition of the principle into French law, it has been possible to oppose the precautionary principle in administrative decision-making ${ }^{65}$. The administrative courts were using the precautionary principle 'legislative right' in areas such as GMOs $^{66}$ and insecticides ${ }^{67}$ before extending the scope of control to general environmental protection and public health. Many examples have been seen particularly in the area of GSM (mobile phone) antennas as for instance a case before the Cour Administrative d'Appel (CAA) de Marseilles ${ }^{68}$ in 2002, relating to the matter of a planning permission granted to a GSM operator for a mast that was contested for health reasons (application of the precautionary principle). The permission was granted, contested before the lower administrative court, which confirmed the permission. It was then quashed in appeal before the CAA on the basis of the precautionary principle. While in the same year, in a similar matter, a decision to refuse permission to erect a mast founded on the precautionary principle was suspended by the Conseil d'Etat. ${ }^{69}$ In this case, the supreme administrative court was applying the precautionary principle in a very cautious way rather than in an extensive way because the court, on the basis of expert evidence, did not consider that the mast was a proven health risk. Now, following the constitutionalisation of Charter and specifically the precautionary principle, a local authority must consider the possibility of health risks in its decisions, 'even if scientific knowledge is uncertain'. If a decision is then considered by an administrative court the character of uncertainty of risk to health will provide fundamental grounds for the courts ruling. Hence, the Charter creates a jolt in the public sphere, firstly by renewing the 'spirit' of the precautionary principle, and secondly by putting it in the symbolic position in a 'bill of rights'. The

64 Décision DC 2007-548, JORF 28 February 2007, 3683 (Loi relative aux règles d'urbanisme applicables dans le périmètre de l'opération d'intérêt national de La Défense et portant création d'un établissement public de gestion du quartier d'affaires de La Défense). This bill was declared to be in conformity with the Constitution.

65 Remarkably, the Conseil d'Etat was using a similar way to protect the environment even before the transposition of the precautionary principle in French law. See CE, 4 January 1995, Ministere de l'Interieur c/Rossi, n 94967.

66 CE, 25 September 1998, Association Green Peace France, n 194348.

67 CE, 29 October 1999, Société Rustica Programme Génétique SA et autres, n 206687 \& 206373.

68 AA Marseilles, 13 June 2002, Association AIPE c/Commune de Cagnes sur Mer, n 97MA05052.

69 CE, 22 August 2002, SFR c/ Commune de Valauris, n 245624. 
unforeseen wider scope of the Charter was immediately seen by environmental associations, ecologists, and activists. .

In April 2005, a local administrative court, the tribunal administratif of Châlons-enChampagne, ${ }^{70}$ was given the task, of checking an alleged attack on civil liberty committed by an act of the préfet de la Marne, (this is the representative of the central state in one of the administrative units of Metropolitan France, namely the department de la Marne). The préfet decided to authorise a rave party on a former military field the airport of Marigny, which is considered of high environmental value. ${ }^{71}$ This decision was challenged by several environmental groups, who considered that it was against a fundamental freedom, namely the right to an environmental protection. ${ }^{72}$ These groups asked the judge using a référé liberté, an emergency summary procedure, to suspend this authorisation. The procedure of référé liberté ${ }^{73}$ used implied the existence of a fundamental freedom. It operates when a public authority or a private organisation in charge of a mission of public service has allegedly breached a fundamental freedom in one of its decisions. ${ }^{74}$ The judge considered in its ordonnance dated 29 April 2005, that the administrative decision of the préfet had to be suspended on the basis of article 1 of the Charter. ${ }^{75}$ The Charter was consecrated here as containing fundamental freedoms considered to be of constitutional value. ${ }^{76}$ The summary procedure was confirmed by a judgment dated the 4 May 2006 in the same jurisdiction.

More recently, the Charter was used to argue against the re-introduction of bears in the Pyrenean areas. ${ }^{77}$ Twenty-six parties, including five communes, 1 département, and 20 associations of farmers argued that the decision by the Minister for Ecology and Sustainable Development of introducing five Slovene bears in order to re-populate the Pyrenees, should be suspended. One of the grounds on which the challenge was upheld was that the participation principle enshrined in the Charter had not been respected because the appropriate consultation had been partial and limited to a certain area in the Pyrenees. This case proves the wider utilisation of the Charter. As stressed previously, constitutional control that was supposed to be the sole point of the Charter has now evolved. In this case, the farmers tried to use the Charter to prevent the reintroduction of

70 TA Châlons-sur-Marne 29 April 2005, AJDA 2005, 978.

71 The airport of Marigny presents many species of communitarian interest and is designated as an important area of bird conservation by the directive 79-409 79/409/CEE 2 April 1979 modified . The site is now integrated into the Natura 2000 network (Arrêté du 10 mars 2006 portant désignation du site Natura 2000 Marigny, Superbe, vallée de l'Aube (zone de protection spéciale), JO n 60 du 11 mars 2006 page 3726, texte $n^{\circ} 48$ ).

72 Three major associations were involved: Conservatoire du Patrimoine Naturel de Champagne-Ardenne, la Ligue de Protection des Oiseaux and la Fédération des Conservatoires d'Espaces Naturels.

73 Article L.521-2 of the Code de justice administrative

74 Two conditions are set up by art. L 521-2 du Code de justice administrative to initiate the emergency summary procedure, that are the seriousness of the "attack" on the fundamental freedom and the obvious illegality of the decision.

75 It was commented by the judge that the Charter contains the right to live in a balanced environment respectful of health (le droit de chacun de vivre dans un environnement équilibré et respectueux de la santé), and that the right to environment (le droit a l'environnement) is a fundamental freedom in the meaning of article L. 521-2 du Code de justice administrative.

76 The Conseil d'Etat has, since the innovation of the référé liberté in 2000, considered as fundamental freedoms those such as the freedom of reunion, right of asylum and the right to own a property. It seems that the Conseil d'Etat is getting back its role of protection of civil and political rights and freedoms creation, recognition and protectionist had before the creation of the Conseil constitutionnel (indeed the Conseil d'Etat was the main source of protection of civil and political rights and freedoms during the French third and fourth Republics).

77 Ordonnance du juge des référés du 9 mai 2006, Fédération Transpyrénéenne des Eleveurs de Montagne et autres, $\mathrm{n}$ 292398 http://www.conseil-etat.fr/ce/jurispd/index_ac_ld0625.shtml (last accessed 20 October 2006).

E N V L R E V $\left.10 \begin{array}{llllllll}2 & 0 & 0 & 8\end{array}\right) \quad 9-27$ 
the bears hence appropriating the Charter for their own benefit. The court saw this and thus their action was unsuccessful.

The Conseil d'Etat has been employing a rather indirect, perhaps limited, way of applying the Charter. In February 2006, on the same day, two cases used references to the new constitutional principle, the precautionary principle. ${ }^{78}$ Both parties in both cases were arguing whether or not the precautionary principle was breached by the defendant. The different outcomes had nothing to do with the application of the Charter but the most important point here is the utilisation of the precautionary principle as a ground to seek administrative justice. What is evident in the matter of administrative justice is that the lower courts are less reluctant to consider environmental issues than the highest court. Indeed, the Conseil d'Etat, in its first rulings after the Charter was integrated into the Constitution, restricted the Charter's use. ${ }^{79}$ The supreme administrative court therefore kept in line with its function of control of legality (in opposition to the function of the Conseil constitutionnel which controls constitutionality). If the Charter has become valued as a legal instrument that can now be considered in any administrative courts, the way the courts will use this instrument remains unclear. As mentioned, the precautionary principle may be used as a legal basis for the arguments of defendants, while the Conseil d'Etat may be willing to consider the legality of administrative decision towards articles 1 , 2 and 6 of the Charter. Then again, it is normal for the supreme administrative court to only analyse the legality of an administrative decision rather than its constitutionality.

The Charter has had an impact on the civil and criminal courts as well. Environmental law in France has always been considered as a special branch of droit administratif. In consequence, environmental issues were absent from civil and criminal courts. The reclassification of certain environmental rights at constitutional level created a certain dynamic in these courts. Immediately, the Charter was seen as an 'operating bill', enshrining rights that have to be protected. It may be interesting to analyse the differences between before and after the approval of the Charter with regards to legal actions brought against activists attacking experimental GMO crops. On 25 July 2004, the first national meeting of the Faucheurs Volontaires resulted in the neutralising of GMO seed plantation. ${ }^{80}$ On 8 November 2004222 activists were involved and were convicted by the Tribunal Correctionel of Toulouse, a criminal court of first instance. On appeal, on 15 November 2005, the Cour d'Appel de Toulouse gave prison sentences to eight activists and awarded damages. ${ }^{81}$ This case was the first one to reach the level of the supreme court of the civil and criminal justice system..$^{82}$ The defendants were trying to get the judgment of the Cour d'Appel de Toulouse quashed on three grounds, one being on the basis that the court did not analyse their facts in the light of the Constitution and particularly the newly adopted Charter. The defence used the idea of 'state of necessity' in this trial and the possibility opened by the Charter to deny criminal responsibility to somebody acting on this

78 CE, 28 April 2006, Fédération des Syndicats Agricoles MODEF, n 274458,274459 http://www.conseil-etat.fr/ ce/jurispd/index_ac_ld0622.shtml and CE, 28 April 2006, Association Générale des Producteurs de Mais et autres, n 269103, 269109, 269686, 269722, 269959, 270004 http://www.conseil-etat.fr/ce/jurispd/index ac_ld0621.shtml (last accessed 20 March 2007).

79 CE, 6 April 2006, Ligue pour la protection des oiseaux (LPO), n 283103 and CE, 19 June 2006, Association Eau et Rivières de Bretagne, n 282456.

80 The first 'operation' of field cutting of GMO crops was held in France on 7 June 1997 in Saint-Georges d'Esperanche. 3 activists were sentenced in Vienne on 23 April 2003 The Cour d'Appel de Grenoble invoked the presidential amnesty of 2002 to annul the judgment on the first court (26 October 2005).

81 Cour d'appel de Toulouse, 15 November 2005, n 004/01065. http://www.legifrance.gouv.fr/WAspad/ Visu?cid=11874\&indice=1\&table=CAPP\&ligneDeb=1 (last accessed 20 March 2007).

82 H. Kempf, 'La Cour de cassation statuera le 7 février sur le sort judiciaire de José Bové ' Le Monde (Paris) 12 January 2007. 
legal basis. This was prompted by the new developments and the legal construction of Tribunal Correctionel d'Orleans on 9 December 2005 and Tribunal Correctionel of Versailles, on 12 January 2006 (see below). The Cour de cassation on 7 February 2007 rejected every argument, including the one developed on the basis of the Charter. ${ }^{83}$ ' [...] Judges have justified their decision [...], the Charter for the Environment shall not be invoked, in this case, as a basis for the "state of necessity".

The Tribunal Correctionel of Riom on 14 December 2004, followed by the Cour d'Appel de Riom on 14 September 2005 came to a similar conclusion. The Tribunal Correctionel of Riom could not employ the idea of 'state of necessity' in this trial, but could do so at appeal level, because it took place after the modification of the Constitution, although relating to facts dating back to 2004. The Charter could not be considered and the decision of the first court was confirmed. The Tribunal Correctionel of Clermont-Ferrand on 16 September 2005 and the Tribunal Correctionel of Lille on 30 September 2005 gave a prison sentence and awarded damages against, respectively, 12 and 11 activists (there was no appeal in either case).

The two cases which started after the modification of the Constitution (if we exclude the one that went through all the appeal and cassation processes) are more important, at least in terms of legal construction and reasoning, and prove a difference of impact. The Tribunal Correctionel d'Orleans on 9 December 2005 released 49 activists involved in destroying a field of GMO crops. The activists were accused of committing a serious degradation of goods belonging to someone else, a criminal offence, ${ }^{84}$ and were asked to pay a sum in compensation for the civil offence. The court analysed the imminent and actual danger, together with the necessity of the action taken by the activists and finally the proportionality of the means used by the activists. The court considered that there was no criminal offence committed as the activists were in a 'state of necessity'. ${ }^{85}$ Furthermore, the court mentioned that the ECHR article 2 (right to life) had now an equivalent in domestic law through the Charter. It was then mentioned that the 'state of necessity' was justified as a consequence. The Monsanto company appealed the decision, which was quashed on 27 June 2006. The Court d'Appel considered that there was no proof of any imminent or actual danger. As such, the court decided that what had been done by the activists was not necessary. The court finally added that the defendants could not sustain that they had no other possible course of action, while 'the resorts of law were multiple and that an authorisation of dispersal given to Monsanto was quashed by the Conseil d'Etat'. 86

Even more recently, the Tribunal Correctionel of Versailles, on 12 January 2006, used similar reasoning to its counterpart in Orleans. Nine activists, who destroyed a field of GMO crops, were accused of committing a degradation of goods belonging to someone involved in a public service, ${ }^{87}$ and were asked to pay a sum in compensation of the civil offence. The qualification of the offence committed was slightly different to the previous case as the INRA agency (National Institute for Agricultural Research), a 'national public

83 C.Cass. (crim.), 7 February 2007, Actes dits de "fauchage volontaire", n 06-80.108 Arrêt n 220 du 7 février 2007. http://www.courdecassation.fr/jurisprudence_publications_documentation_2/actualite_jurisprudence_ 21/chambre_criminelle_578/arrets_579/fauchage_volontaire_9879.html (last accessed 20 March 2007).

84 Dégradation grave de bien d'autrui commise en réunion.

85 However, they were held to be civilly responsible and required to pay compensation to Monsanto for the civil offence.

86 CE, 28 April 2006, Fédération des Syndicats Agricoles MODEF, n 274458,274459 http://www.conseil-etat.fr/ce/ jurispd/index_ac_ld0622.shtml (last accessed 20 October 2006).

87 Destruction de bien d'un charge de mission de service public.

E N V L R E V $\left.10 \begin{array}{llllllll}2 & 0 & 0 & 8\end{array}\right) \quad 9-27$ 
scientific and technological establishment [...] under the joint authority of the Ministries of Research and Agriculture', ${ }^{88}$ was involved. ${ }^{89}$ The court considered that there was no criminal offence ${ }^{90}$ again on the grounds that the activists were in a 'state of necessity'. Furthermore, the court combined the ECHR articles 2 and 8, right to life and right to the respect of the private life, with the right to a healthy environment. Finally, it declared that the right to a healthy environment has now an equivalent in domestic law through the Charter. It was then mentioned that the 'state of necessity' was justified as a consequence. The Court d'Appel de Versailles, on 22 March 2007, quashed this decision. The same justification was exposed here. It was considered that there was no proof of any imminent or actual danger. Once more, the court decided that what had been done by the activists was not necessary.

To resume, it can be argued that the situation is similar in administrative and civil/criminal courts: The higher courts have taken a conservative traditional approach that is considering the Charter as solely a document for constitutional control (therefore under the remit of the constitutional court). In contrast, the lower courts have been involved in a progressive development. They have departed from the classic method of operating and allowed wider applications of the Charter. In that respect, the Charter's first years afforded a tremendous opportunity that has, so far, not been brought to fruition.

\section{CONCLUSION}

In 2005, with the extension of the scope of constitutional review via the Charter for the Environment, an increased consideration of environmental issues in French law was predicted. However, it has developed beyond all predictions during the first two years of enforcement.

The Charter was the result of the conscious will of President Chirac, one man's idea that developed into a national document the people were supposed to embrace. The document was formerly raised to the status of the highest law of the land. Technically, it was only supposed to be a document enshrining environmental issues in an ageing Constitution. The Charter was designed to hang on the wall of public services offices and official buildings, near the 1789 Declaration. The outcome, we have seen, is radically different. The Charter was utilised as a real 'bill of rights'. It rapidly became a tool used outside the strictly public sphere by activists seeking to protect themselves while appearing, in the eyes of the State, as acting in a criminal way.

It creates a positive and a negative aspect. The positive is that the dust will not settle on the Charter like it may have done on other 'bills of rights'. It has, is and will be used not only to oppose the will of the majority in the French parliament through the use of the control of Conseil constitutionnel, but also by the people or at least those who think about environmental issues. The negative aspect is that in the course of being used as a bill for the environment, it has the potential of becoming a guise to absolve 'crimes' committed by activists. The Charter protects against use and abuse of the environment by humans, for the sake of humanity, but it ends up protecting alleged criminals fighting against the society as it exists and, in consequence, the rights that it creates. Perhaps, the meaning of crime in that case is questionable and what these activists are doing may elevate them to heroes in the future. As said by the Austrian philosopher Wittgenstein, 'The limits of my

88 http://www.inra.fr/ENG/INRA_OVERVIEW/overview.html (last accessed 20 October 2006).

89 Although Monsanto appeared to be still present behind INRA.

90 They were held to be civilly responsible and had to pay no compensation. 
language means the limits of my world'. ${ }^{91}$ In the case of French constitutional norms, the language has increased to consider and include environmental issues and their protection. Does this mean the limits of the Constitution have increased as well?

Technically, there has been a normative increase of the Constitution. In practice, what was expected was clearly modest compared to what has really happened. The effects have been broader than mere constitutional control. Perhaps, the will of the President matched that of the people and this is one reason for the current development. Perhaps, the President intended a radical development. The philosophical debate between authoritarian option and democratic option in environmental protection, as exposed by Bourg and Jonas, ${ }^{92}$ moved from the legal formalism to a rather practical development. It is so important that it transpired through the few cases mentioned above. One may consider that cutting crops, in the manner it had been done, by organised activists, is an authoritarian way of operation. The lower courts have, in this respect, supported their actions, using the Charter to protect them. What the supreme courts, have done, on the contrary, has been to counter balance this authoritarian approach and give way to a democratic approach.

What is important is that constitutionalisation of rights in a non-flexible written legal Constitution, like the French one, allows for a greater protection of rights. What is probably more important is how to rightly use these rights.

\section{Article 2 of Constitutional amendment incorporating the Charter for the Environment into the French constitution ${ }^{93}$.}

Article 2

The Charter for the Environment of 2004 is thereafter drafted:

"The French People,

"Considering,

"That resources and natural equilibrium have conditioned the rise of humanity;

"That the future and the very existence of humanity can not be dissociated from its natural environment;

"That environment is the common heritage of the human race;

"That humans increasingly influence living conditions and their own evolution;

"That the biological diversity, the blossoming development of person and the progress of human societies are affected by some modes of consumption or production and by excessive exploitation of natural resources;

"That preservation of the environment has to be sought on the same level than other fundamental interests of the Nation;

91 L. Wittgenstein, Tractatus Logico Philosophicus (Routledge: London, 2001) 66.

92 See Dowson, Lucardie, above n. 32.

93 Loi constitutionnelle $n^{\circ} 2005-205$ du ler mars 2005 relative à la Charte de l'environnement (1), JO $n^{\circ} 51$ du 2 mars 2005 page 3697. Unofficial translation by the author.

E N V L R E V $\left.10 \begin{array}{lllllllll}2 & 0 & 0 & 8\end{array}\right) \quad 9-27$ 
"That in order to ensure a sustainable development, choices made to answer current demands should not compromise the capacity of future generations and of other Peoples to satisfy their own needs;

"Proclaim:

"Art 1- Everyone has the right to live in a balanced environment which respects health.

"Art 2- Everyone shall take part in the preservation and improvement of the environment.

"Art 3 - Everyone shall, within the limits imposed by Statute Law, prevent possible damages to the environment one may create or, failing that, limit their consequences.

"Art. 4. - Everyone shall contribute to repairing damages one causes to the environment, within the limits imposed by Law.

"Art. 5. - Even if scientific knowledge is uncertain where damages occur which could have serious and irreversible effects on their environment, public authorities shall within their own domains of competences, apply the precautionary principle through the implementation of procedures for the evaluation of risks, and the adoption of provisional and proportionate measures in order to prevent the damage occurring.

"Art. 6 . - Public policies must promote a sustainable development. To this purpose, they conciliate protection and valorisation of the environment, economic development and social progress.

“ Art. 7. - Everyone has a right, within the conditions and limits of Law, to access information relating to the environment in the possession of public authorities and to participate in the public decision making process which have an incidence on the environment

"Art. 8. - Education and formation on the environment have to contribute to the exercise of rights and duties listed in the present charter.

"Art.9. - Research and innovation should contribute to the preservation and the improved development of the environment.

"Art. 10. - The present Charter inspires European and international action of France. 